\title{
Seed morphology and sculpture of invasive Impatiens capensis Meerb. from different habitats
}

\author{
Agnieszka Rewicz ${ }^{\text {Corresp., } 1}{ }^{1}$,Monika Myśliwy ${ }^{2}$, Wojciech Adamowski ${ }^{3}$, Marek Podlasiński $^{4}$, Anna Bomanowska $^{1}$ \\ 1 Department of Geobotany and Plant Ecology, University of Lodz, Lodz, Poland \\ 2 Institute of Marine and Environmental Sciences, University of Szczecin, Szczecin, Poland \\ 3 Białowieża Geobotanical Station, Faculty of Biology, University of Warsaw, Białowieża, Poland \\ 4 Department of Environmental Management, West Pomeranian University of Technology, Szczecin, Poland \\ Corresponding Author: Agnieszka Rewicz \\ Email address: agnieszka.rewicz@biol.uni.lodz.pl
}

Impatiens capensis is an annual plant native to eastern North America that is currently spreading across Europe. In Poland, due to this plant's rapid spread in the secondary range and high competitiveness in relation to native species, it is considered a locally invasive species. The microstructure of seeds is an important tool for solving various taxonomic problems and also provides data useful for determining the impact of various environmental factors on the phenotypic variability of species. This issue is particularly important regarding invasive species which occupy a wide range of habitats in the invaded range. There are few reports on seed size and thus far no descriptions of the seed ultrastructure of $I$. capensis in the analyzed literature. We present new data on the seed morphology of $I$. capensis growing in different habitats and conditions in the secondary range of the species. The studied populations differed significantly in each of the investigated traits (seed length, width, circumference, area, roundness, and mass). Our findings showed that anthropogenic disturbances in habitats and some soil parameters (presence of carbonates, potassium, loose sand, and moisture) were statistically significant with various seed sizes and morphology in the studied populations of $I$. capensis. Moreover, our studies showed maximum seed length $(5.74 \mathrm{~mm})$ and width $(3.21 \mathrm{~mm})$ exceeding those values given in the available literature. For the first time, we also provide a detailed SEM study of the ultrastructure of the seed coat of $I$. capensis. There are two types of epidermal cells on the seeds: a) between the ribs (elongated with straight anticlinal walls, slightly concave outer periclinal walls, and micropapillate secondary sculpture on the edges with anticyclic walls), and b) on the ribs (isodiametric cells with straight anticlinal walls and concave outer periclinal walls). Unlike the variability of size and weight of seeds, the coat ornamentation has turned out to be a steady feature within the studied secondary range of $I$. capensis. 
1 Seed morphology and sculpture of invasive Impatiens capensis Meerb. from different 2 habitats

3

4 Agnieszka Rewicz ${ }^{1}$, Monika Myśliwy², Wojciech Adamowski ${ }^{3}$, Marek Podlasiński ${ }^{4}$, Anna $^{2}$ 5 Bomanowska ${ }^{1}$

$7{ }^{1}$ University of Lodz, Faculty of Biology and Environmental Protection, Department of

8 Geobotany and Plant Ecology, Banacha 12/16, 90-237 Lodz, Poland, e-mail:

9 agnieszka.rewicz@biol.uni.lodz.pl

${ }^{2}$ University of Szczecin, Institute of Marine and Environmental Sciences, Adama Mickiewicza

16, 70-383 Szczecin, Poland

${ }^{3}$ University of Warsaw, Białowieża Geobotanical Station, Faculty of Biology, Sportowa 19, 17230 Białowieża, Poland

${ }^{4}$ West Pomeranian University of Technology, Department of Environmental Management, Słowackiego 17, 71-434 Szczecin, Poland

\section{Abstract}

Impatiens capensis is an annual plant native to eastern North America that is currently spreading across Europe. In Poland, due to this plant's rapid spread in the secondary range and high competitiveness in relation to native species, it is considered a locally invasive species.

The microstructure of seeds is an important tool for solving various taxonomic problems and also provides data useful for determining the impact of various environmental factors on the phenotypic variability of species. This issue is particularly important regarding invasive species which occupy a wide range of habitats in the invaded range.

There are few reports on seed size and thus far no descriptions of the seed ultrastructure of $I$. capensis in the analyzed literature.

We present new data on the seed morphology of $I$. capensis growing in different habitats and conditions in the secondary range of the species. The studied populations differed significantly in each of the investigated traits (seed length, width, circumference, area, roundness, and mass). Our findings showed that anthropogenic disturbances in habitats and some soil parameters (presence of carbonates, potassium, loose sand, and moisture) were statistically significant with 
32 various seed sizes and morphology in the studied populations of I. capensis. Moreover, our studies showed maximum seed length $(5.74 \mathrm{~mm})$ and width $(3.21 \mathrm{~mm})$ exceeding those values given in the available literature.

For the first time, we also provide a detailed SEM study of the ultrastructure of the seed coat of $I$. capensis. There are two types of epidermal cells on the seeds: a) between the ribs (elongated with straight anticlinal walls, slightly concave outer periclinal walls, and micropapillate secondary sculpture on the edges with anticyclic walls), and b) on the ribs (isodiametric cells with straight anticlinal walls and concave outer periclinal walls). Unlike the variability of size and weight of seeds, the coat ornamentation has turned out to be a steady feature within the studied secondary range of $I$. capensis.

Keywords: Balsaminaceae, environmental factors, invasive species, scanning electron microscopy (SEM), seed coat, variability, 3D ultrastructure

\section{Introduction}

The genus Impatiens is the most species-rich within the family Balsaminaceae, with ca. 1000 species distributed primarily in the Old World tropics and subtropics (Grey-Wilson 1980; Yu et al. 2015).

Impatiens has been a subject of numerous studies regarding distribution (Zhou et al. 2019), ecology (Abrahamson, Hershey 1977; Boyer et al. 2016), physiology (Nanda, Kumar 1983; Tooke et al. 2005), biochemistry (Sreelakshmi et al. 2018), biology (Jacquemart et al. 2015), pollination (Abrahamczyk et al. 2017), morphology (Akiyama, Ohba 2000; Janssens et al. 2018), systematics (Chen et al. 2007a, b; Gogoi et al. 2018), phylogeny and evolution (Janssens et al. 2007; Ruchisansakun et al. 2015), and other (see Adamowski 2016 onwards). Despite the plethora of publications on various attributes of Impatiens, this genus requires further attention and research. Impatiens is taxonomically one of the most difficult groups to classify and remains a major challenge due to the enormous species richness and extraordinary morphological variability, with plants ranging from annuals growing only several centimeters high and bearing a single flower to subshrubs four meters high (Hooker 1904-1906; Grey-Wilson 1980; Gogoi et al. 2018; Ruchisansakun et al. 2018). 
62

63

64

65

66

67

68

69

70

The majority of balsam species grow in hardly accessible mountain ranges and have delicate flowers with complex morphology (Bhaskar 2012; Yu 2012; Rahelivololona et al. 2018). Herbarium specimens of balsams are difficult to prepare due to the succulent nature of the stems. Specimens require special preparation such as floral dissection (Shui et al. 2011); field notes are otherwise of limited value. Flower colors fade quickly and the position of the individual flower parts is often impossible determine from traditionally prepared specimens. One of the taxonomically important features within the genus Impatiens is related to the morphology of seeds. First information on the diversity of the seed coat of Impatiens was reported by Hooker and Thomson (1859) and Warburg and Reiche (1895). Other works were concerned mostly with the shape and size of seeds rather than details of their surface ornamentation (Shimizu 1977).

The development of new imaging methods enables the observation and study of ultrasmall-sized structures. Scanning electron microscopy (SEM) has allowed a detailed analysis of seed coat micromorphology of Impatiens seeds (Song et al. 2005; Chen et al. 2007a; Zhang et al. 2016). Earlier works focused on seed dimensions were rarely devoted to the ultrastructure of seeds (Shimizu 1979; Lu, Chen 1991). The sculpture on seed coats offers a set of characters which can be used to identify a species, and in combination with other morphological data, can provide crucial evidence towards the taxonomy of a genus (Lu, Chen 1991; Song et al. 2005; Utami, Shimizu 2005; Cai et al. 2013; Yu et al. 2015).

Seed morphological features of Impatiens have not only been used for solving various taxonomic problems within the genus but also prove to be useful for determining the impact of various environmental factors on the phenotypic variability of balsam species (Argyres, Schmitt 1991; Schmitt 1993; Maciejewska-Rutkowska, Janczak 2016). The understanding of environmentally induced variation in an individual plant phenotype is crucial for predicting population responses to environmental changes. This issue is particularly important regarding invasive species which occupy a wide range of habitats in the invaded range (Richards et al. 2006).

Despite an increasing number of publications on the surface of Impatiens seeds by SEM (e.g., Shimizu 1979; Yu et al. 2007; Shui et al. 2011; Xia et al. 2019 a.o.), there is still a lack of information on the seed micromorphology of the majority of species. In fact, a detailed understanding of the seed morphology of the entire genus Impatiens is missing, despite major studies using novel imaging methods (e.g., Yuan et al. 2004; Ruchisansakun et al. 2015; 
93 Rahelivololona et al. 2018). As yet, only about 170 species have been investigated, which is 94 about one fifth of all known balsams (Maciejewska-Rutkowska, Janczak 2016).

One of the species with morphologically undescribed seeds is Impatiens capensis (jewelweed, orange balsam), an annual plant native to eastern North America (Meusel et al. 1978), which is currently spreading across Europe. Today I. capensis is considered as naturalized in several European countries (Matthews et al. 2015), including Poland, where the species is locally established and invasive due to its rapid spread in the secondary range and high competitiveness in relation to native species, even perennials (Tokarska-Guzik et al. 2012). In Poland, it was found for the first time in 1987 (Pawlaczyk, Adamowski 1991), and it is currently spreading in the Western Pomerania region (Popiela et al. 2015; M Myśliwy, 2017, personal observations). The species occurs in the area of the Szczecin Lagoon and enters alder forests, willow shrubs, rushes and riparian tall herb fringe communities (Pawlaczyk, Adamowski 1991; Myśliwy et al. 2009; M Myśliwy, 2014, personal observations). It also appears in moist anthropogenic habitats, e.g., along roadside ditches (M Myśliwy, 2017, personal observations).

Impatiens capensis is an annual plant growing from $0.5-1.5 \mathrm{~m}$ or more in height. The flowers are 2.5-3.0 cm long and orange with darker patches in the most common f. capensis. The lower sepal forms a light-orange nectar spur, 5-9 $\mathrm{mm}$ long, which is bent at $180^{\circ}$ to lie parallel to the sepal-sac (Zika 2006). Besides color, it differs from the predominantly Eurasiatic I. nolitangere in that the lower sepal is more rapidly constricted into the spur and the position of the spur (Zika 2009). The fruit is a five-valved capsule, $2.0-2.5 \mathrm{~cm}$ long and 0.3-0.5 cm wide, with explosive dehiscence ejecting the seeds (Moore 1968; Gleason, Cronquist 1991; Day et al. 2012). The seeds are laterally compressed, prolate spheroid, with four strong ribs of 5-5.6 $\times 2.7-3.1$ mm (Bojňanský, Fargašová 2007). The weight ranges from 6.4 to $26.9 \mathrm{mg}$ (Simpson et al. 1985). Schemske (1978) recorded $11.5 \mathrm{mg}$ for cleistogamous seeds and $13.3 \mathrm{mg}$ for chasmogamous ones, and Waller (1982) $10.6 \mathrm{mg}$. The seed surface is wrinkled or rough, lusterless, dark-brown, with some roundish and paler spots (Bojňanský, Fargašová 2007).

Numerous studies (several hundred; see Adamowski 2016 onward and the literature cited therein) have been devoted to the ecology, biology, and genetics of this species (e.g., Antlfinger 1989; Schmitt et al. 1985; Donohue, Schmitt 1999; Donohue et al. 2000; Zika 2009; Tabak, von Wettberg 2008; Day et al. 2012). However, a review of the available literature showed a scarcity of data on seed size and a complete lack of information describing the morphological variation of 
124 the seed coat of I. capensis (Schemske 1978; Waller 1982; Simpson et al. 1985; Bojňanský, 125 Fargašová 2007).

126 The aim of our work has been to characterize the micromorphological traits and

127 ultrastructure of $I$. capensis seeds from various habitats and growing conditions and their

128 morphological variability. Anthropogenic changes in habitats were expected as important factors 129 affecting seed micromorphology and ultrastructure.

\section{Materials and methods}

Study sites

Seeds were collected from August to September 2018 (to avoid seasonal variability) from eight populations of I. capensis in Poland. We sampled the entire Polish range of this species from all types of habitats, from natural (alder carrs, hydrophilous tall herb communities along rivers, near water seepages, and along the banks of the Szczecin Lagoon) to anthropogenic (tall herb communities along roadside ditches, transformed forests along artificial canals) (Table 1, Fig. 1). The studied populations were also subject to different lighting conditions, which were scored using a 3-point scale: plants which grew in willow forests and the understory of alder carrs were strongly shaded (3), while those from tall herb communities were partly shaded by solitary trees (2) or exposed to full sun (1). As the height of I. capensis specimens, the location of capsules within the plant (main stem vs. branches), and their derivation from flowers of various types (cleistogamous vs. chasmogamous) may affect seeds weight (Waller 1982), the seeds for our study were collected always from the main stems of 8-10 plants of similar (average for the population) height and from capsules derived from chasmogamous flowers, to minimize the bias. Species nomenclature was adopted from Euro+Med PlantBase (Euro+Med PlantBase).

Biometric and SEM analysis

From 24 to 30 mature seeds were used from each population for biometric analysis. We measured four quantified seed traits: seed length (SL), seed width (SW), seed circumference (SC), and seed area (SA). The seeds were measured as previously described in Rewicz et al.

152 (2017). In order to describe the seed mass, we used 15 seeds from each population. The seeds 153 were weighed with an Ohaus PA 21. We determined roundness by the formula: $\mathrm{R}=4 \times$ area/ $\pi$

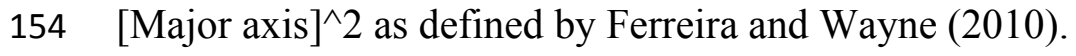


We used eight seeds from each population for SEM. The seeds were air-dried and sputter-

156

157

158

159

160

161

162

163

164

165

166

167

168

169

170

171

172

173

174

175

176

177

178

179

180

181

182

183

184

185

coated with a 4-nm-thick layer of gold (Leica EM ACE200). The SEM work was performed on a Phenom Pro X Scanning Electron Microscope at the Department of Invertebrate Zoology and Hydrobiology, University of Lodz, Poland. The 3D models of the seed surface were generated using the dedicated software $3 D$ Roughness Reconstruction for Phenom. SEM micrographs were analyzed as previously described in Rewicz et al. (2017). Seed shape terminology and types of seed surfaces were adopted from Barthlott (1981).

\section{Soil properties}

In order to characterize habitat conditions at each locality, five soil core samples (0-20 $\mathrm{cm}$ depth) were collected and then mixed together into one composite sample. Soil samples were dried at room temperature, and passed through a sieve to remove fractions larger than $1 \mathrm{~mm}$. The following physicochemical soil parameters were determined (Bednarek et al. 2011), as first described by Myśliwy (2019): organic matter content defined as the loss on ignition (LOI) - soil samples annealed at $550^{\circ} \mathrm{C}(\%)$; grain composition (the content of sand, silt, clay) - Bouyoucos's sedimentation method, modified by Casagrande and Prószyński; granulometric categories according to the PSSS (2009) classification; soil reaction ( $\mathrm{pH}$ ) - the potentiometric method, in 1$\mathrm{M}$ solution of $\mathrm{KCl}$; soil calcium carbonate $\left(\mathrm{CaCO}_{3}\right)$ content $(\%)$ - the Scheibler's method; organic carbon $\left(\mathrm{C}_{\text {org }}\right)$ content $(\%)$, and total nitrogen $\left(\mathrm{N}_{\text {tot }}\right)$ content $(\%)$ were determined by an elemental analyzer CHNS/O FlashSmart (Thermo Scientific), and the $\mathrm{C} / \mathrm{N}$ ratio; the content of available forms of soil nutrients ( $\mathrm{mg} / 100 \mathrm{~g}$ soil): calcium $(\mathrm{Ca})$ and sodium $(\mathrm{Na})$ were determined spectrophotometrically ( $\mathrm{Ca}$ - AAS and $\mathrm{Na}-\mathrm{EAS}$ ) on ICE3000; potassium $(\mathrm{K})$ and phosphorus (P) - measured according to the Egner-Riehm method; magnesium (Mg) - measured by

Schachtschabel's method; soil moisture content, hand-felt assessed directly in the field using a 4point scale recommended by the Soil Science Society of Poland (2017): (1) dry (the soil crumbles and turns to dust, it is neither cool nor moist to touch; it darkens visibly after wetting), (2) fresh (the soil feels cool, but no moisture is felt; darkens after wetting), (3) moist (the soil moistens fingers and tissue paper, but water does not leak when squeezed; clayey, loamy, and some dusty soils are plastic; does not darken after wetting), (4) wet (water leaks from the soil when squeezed, aggregates, soil smears). 
186

187

188

189

190

191

192

193

194

195

196

197

198

199

200

201

202

203

204

205

206

207

208

209

210

211

212

213

214

215

216

\section{Data analysis}

The five following basic characteristic traits were calculated: arithmetic average (x), minimum and maximum values ( $\mathrm{min} / \mathrm{max})$, coefficient of variation $(\mathrm{CV})$, and standard deviation (SD). The distribution of the data was not normal; statistical analysis was based on the KruskalWallis test (for $p \leq 0.05$ ), which is a nonparametric alternative to ANOVA (Zar 1984).

Correlation between pairs of morphological characters was evaluated using Spearman's correlation coefficient and the values were adopted after Meissner (2010), (correlation: less than 0.20 - very poor; 0.21-0.39 - weak; 0.40-0.69 - moderate; 0.70-0.89 - strong; and above 0.89 very strong).

The cluster analysis based on the nearest neighbor method was performed using the matrix on the population's mean values. As the dataset required a linear response model (Jongman et al. 1995), the Redundancy Analysis (RDA) was used to relate the variability of morphological traits of seeds to environmental variables. The variables $\mathrm{C}_{\text {org }}$ and $\mathrm{N}_{\text {tot }}$ were excluded from the RDA as they were strongly correlated with organic matter content (LOI). The Monte Carlo permutation test with the forward selection of environmental variables was applied to determine the importance and statistical significance of variables in explaining the variability in seeds. The software packages Canoco v.4.5 (ter Braak, Šmilauer 2002), MVSP 3.2 (Kovach 2010), and STATISTICA PL. ver. 13.1 (Stat-Soft Inc. 2011) were used for all analyses (van Emden 2008; Lepš, Šmilauer 2003).

\section{Results}

Biometric analysis

Seeds from the $\mathrm{G}$ (Police) population were the largest, with average values of length (SL) $4.60 \mathrm{~mm}$, width (SW) $2.71 \mathrm{~mm}$, circumference (SC) $11.65 \mathrm{~mm}$, and area (SA) $9.26 \mathrm{~mm}^{2}$; comparatively large seeds were also obtained from the E population (Święta); the B (Lubin) population had the shortest (mean SL $3.88 \mathrm{~mm}$ ) and narrowest seeds (mean SW $2.03 \mathrm{~mm}$ ) (Table 2).

The minimum values of analyzed traits were also recorded in the B (Lubin) population (SL $3.16 \mathrm{~mm}$, SW $1.12 \mathrm{~mm}$, SC $7.27 \mathrm{~mm}$, SA $2.43 \mathrm{~mm}^{2}$ ). The maximum values of length $(5.74$ $\mathrm{mm})$, circumference $(14.59 \mathrm{~mm})$, and area $\left(13.54 \mathrm{~mm}^{2}\right)$ were recorded in the $\mathrm{G}$ population (Police). 
A very strong Spearman correlation $(\mathrm{r}=0.94)$ was observed between the seed area and

218

219

220

221

222

223

224

225

226

227

228

229

230

231

232

233

234

235

236

237

238

239

240

241

242

243

244

245

246

247 circumference (Table 3$)$. The most variable features were the seed area $(\mathrm{CV}=21.76 \%)$ and width $(\mathrm{CV}=15.35 \%)$. The variation of seed traits ranged insignificantly from $6.19 \%(\mathrm{H}$ population) to $10.28 \%$ (B) for SL; from $7.30 \%$ (D) to $20.57 \%$ (B) for SW; from $6.22 \%$ (H) to $11.42 \%$ (B) for SC; and from $13.88 \%$ (D) to $26.06 \%$ (B) for SA, respectively.

The G (Police: $11.42 \mathrm{mg}$ ) and E (Święta: $9.82 \mathrm{mg}$ ) populations are characterized by the heaviest seeds. The lightest seeds were observed in the following populations: B (Lubin: 6.52 mg) and H (Trzebieradz: $6.92 \mathrm{mg}$ ) (Fig. 2, Table 2).

The Kruskal-Wallis test showed that the I. capensis populations differed significantly in each of the analyzed traits. The conducted post hoc test (DunnTest) showed that the populations from: Police (G), followed by Czarnocin (D), Święta (E), and Trzebieradz (H) showed the greatest variation in terms of studied traits among all the populations (Table 4).

The similarity analysis using Euclidean's distances showed two main clusters (Fig. 3). The first cluster included six populations of I. capensis (A-D, F, H), all derived from natural habitats, while the other cluster groups two populations $(E, G)$ from anthropogenic habitats, where the examined plants were the highest (Table 1). According to the dendrogram (Fig. 3), populations $\mathrm{C}$ and $\mathrm{F}$ are the closest to each other; both were associated with river valleys (Dziwna and Oder rivers, respectively) and close to the river bed, hence under the influence of flooding. The $\mathrm{D}$ and A populations were growing in tall herb communities on the banks of the Szczecin Lagoon. The most distinct populations in the first cluster (H and B) were also found on the banks of the Szczecin Lagoon, but they had the lowest average height and differed in habitat conditions from the other populations of this cluster (Table 1).

The investigated morphological parameter of seed shape, roundness, showed statistically significant differences between the populations $(p<0.05)$. For roundness, the highest value was recorded at D: Czarnocin (0.58) (tall herbs on the bank of the Szczecin Lagoon) and the lowest at H: Trzebieradz (0.47) (alder carr) (Table 5).

Biometric variability of seeds and its relationship with environmental conditions

All environmental variables included in the RDA accounted for $35.6 \%$ of the total variation. The results of stepwise forward selection of variables indicated that five variables: anthropogenic disturbances (Anthrop), carbonates $\left(\mathrm{CaCO}_{3}\right)$, loose sand presence (LoSa), 
248 potassium $(\mathrm{K})$, and soil moisture content (Moist) were statistically significant and varied

249 between the studied populations of I. capensis (Fig. 4). Along the gradient represented by Axis I,

250 the highest correlation between the sample position and environmental variables (the so-called

251 interset correlation) was typical of anthropogenic disturbances and $\mathrm{CaCO}_{3}$, followed by the

252 degree of shading and soil $\mathrm{Ca}$, while the $\mathrm{C} / \mathrm{N}$ ratio was most closely correlated with Axis II,

253 followed by soil content of $\mathrm{P}, \mathrm{Na}, \mathrm{K}$, and organic soil.

254 The location of population H (Trzebieradz) in the ordination space (the upper part of the

255 RDA diagram) was associated with the highest $\mathrm{C} / \mathrm{N}$ ratio, the highest soil moisture and shading,

256 as well as with the lowest soil $\mathrm{pH}$ and the lowest soil content of $\mathrm{CaCO}_{3}, \mathrm{Ca}$, P, and $\mathrm{K}$ (Fig. 4,

257 Table 6). At the same time, the $\mathrm{H}$ population was dominated by short specimens (Table 1), with

258 one of the lightest seeds and average values of biometric traits (Table 2). In contrast, populations

259 characterized by the longest, widest, and heaviest seeds, from E (Święta) and G (Police), located

260 in the right-hand side of the RDA diagram, were also related to a relatively high $\mathrm{C} / \mathrm{N}$ ratio, but

261 unlike the previous population, they were associated with a low level of soil moisture as well as

262 the highest anthropogenic disturbances (Fig. 4), and consisted of the tallest specimens (Table 1).

263 Population D (Czarnocin) occupied the bottom part of the diagram and was distinct in its organic

264 soil, with the highest content of organic matter (LOI), as well as $\mathrm{P}, \mathrm{K}, \mathrm{Mg}$, and $\mathrm{Na}$ content in the

265 soil, while having the lowest $\mathrm{C} / \mathrm{N}$ ratio (Table 6). The lowest values of the seed biometric traits

266 were found for population B (Lubin), located in the left-hand part of the RDA diagram (Fig. 4,

267 Table 2), and associated with high soil $\mathrm{pH}$ and the highest content of soil carbonates and

268 calcium, as well as a low level of soil moisture (Table 6). The other populations (A: Podgrodzie;

269 C: Unin; F: Szczecin-Zdroje) were also on the left side of the diagram, but closer to the center

270 (Fig. 4). Neither their seed biometric traits nor habitat conditions were distinct (Tables 2, 6).

271

272

273

274

275

276

277

278

\section{Seed surface ultrastructure}

The studied seeds of I. capensis were round in shape, with a lusterless, rough, and darkbrown surface, without roundish and paler spots (Fig. 5). The seeds had four strong, clear ribs, the apex and bottom narrowed. Each rib was built of rows of 4-5 cells and had a darker color than the surface between them (Fig. $5 \mathrm{H}$ ). The seed coat is composed of two types of epidermal cells (Fig. 5 E, H) creating a net-like pattern. The cells of the seed surface between the ribs were: elongated with straight anticlinal walls (Fig. 5 E), raised cell boundaries between the cells (Fig. 5 
279 G), slightly concave outer periclinal walls (Fig. 5 F, G) and a micropapillate secondary sculpture 280 on the edges of anticyclic walls (Fig. 5 F). Near the ribs, there were rows of 4-7 isodiametric 281 cells (Fig. 5 I, K) with straight anticlinal walls (Fig. 5 L), with raised cell boundaries (Fig. 5 M)

282 and concave outer periclinal walls. Seeds from all studied populations did not differ in their 283 ultrastructure (Fig. 5 A - D).

284

285

ultrastructural characteristics which helps or identifying and determining the taxonomic delimitation of various angiosperm groups, as demonstrated for Brasssicaceae (Tantaway et al. 2004), Caryophyllaceae (Ullah et al. 2019a, 2019b), Poaceae (Martín-Gómez et al. 2019b), Cyperaceae (Więcław et al. 2017), Ranunculaceae (Constantinidis et al. 2001; Rewicz et al. 2017; Martín-Gómez et al. 2019a; Hadidchi et al. 2020), Rosaceae (Ballian, Mujagić-Pašić 2013), Onagraceae (Akbari, Azizian 2006), and Orchidaceae (Gamarra et al. 2007, 2010; Rewicz et al. 2016). Although seed morphology alone does not provide universally applicable key characters for species identification, it can be as helpful as many other characters used in taxonomy.

Members of Balsaminaceae have a diverse and elaborately sculptured seed coat. Unfortunately, till now seed morphology has been observed only for a small number of Impatiens species, which has limited the use of the morphological traits of seeds in taxonomy and classification (e.g. Song et al. 2005; Utami, Shimizu 2005; Chen et al. 2007a; Yu et al. 2007; Jin et al. 2008; Shui et al. 2011).

We here provide new data about the seed morphology and seed coat sculpture of $I$. capensis, as well as new information about the area of its distribution in Poland. Our studies have shown maximum seed length $(5.74 \mathrm{~mm})$ and width $(3.21 \mathrm{~mm})$ beyond the values reported elsewhere. Bojňanský and Fargašová (2007) found seeds of I. capensis to be 5-5.6 mm long and 2.7-3.1 mm wide. Our ultrastructural studies have shown two types of cells on between the ribs and on the ribs, that have previously not been described (Fig. 5). The occurrence of several types of epidermal cells on the seeds of members of Impatiens was previously noted, for instance, three types of epidermal cells have been reported in Impatiens aconitoides Shui et al. (2011). We were not able to confirm in any of our studied populations the presence of roundish spots on the 
310 surface of seeds (Fig. 6) as reported by Bojňanský and Fargašová (2007), which may be due to

311 the different geographical origin of the examined seeds: our seeds of I. capensis are from wild-

312 growing populations from various habitats, while those studied by Bojňanský and Fargašová

313 (2007) were obtained from cultivation and of unknown origin.

314 The analysis of SEM micrographs of I. noli-tangere seeds closely related to I. capensis

315 (Yu et al. 2015) has shown that seed coats of this species vary significantly depending on the

316 geographical origin of the seeds (Utami, Shimizu 2005; Chen et al. 2007 a; Jin et al. 2008). On

317 the other hand, the comparison of the seed micromorphology of I. capensis has not shown

318 similarity to seed coat ornamentation of the aforementioned I. noli-tangere (with narrow and

319 ellipsoid seeds, fine reticulate subtype, testa cells with reticulate thickened outer walls; Song et

320 al. 2005; Utami, Shimizu 2005; Chen et al. 2007a; Jin et al. 2008). Despite the fact that both

321 species are closely related and may be confused (Zika 2009; Yu et al. 2015), their seeds clearly

322 differ morphologically. The new data presented here may be useful in the identification of these

323 species. In turn, there is no information about the seed morphology of I. pallida, which is

324 sympatric and synchronic species to I. capensis (Rust 1977), which makes this subject even more

325 difficult. Elucidating the overall variation in seed coat micromorphology and to implement this

326 feature to taxonomy of $I$. capensis will require more samplings, also within the native range of

327 orange jewelweed as well as other closely related species and this eventually should become the

328 basis for further comparisons and studies. Seed ultrastructure appears to be a constant feature

329 within a taxonomic unit (Stace 1992) and, as morphological studies show, seed shape and size

330 are highly diverse at the genus and species levels (Yu et al. 2007; Jin et al. 2008; Shui et al.

331 2011; Ullah et al. 2019a, 2019b; Hadidchi et al. 2020). Both statements have been proven for $I$.

332 capensis in Poland.

333 Data concerning the size, shape and structure of seeds not only have been used as an

334 important tool for solving various taxonomic problems within the genus Impatiens but also

335 provide results useful for determining the impact of various environmental factors on the

336 phenotypic variability of these species (Bell et al. 1991; Argyres, Schmitt 1991; Schmitt 1993;

337 Chmura et al. 2013; Maciejewska-Rutkowska, Janczak 2016).

338 Environmental heterogeneity is indicated as a major factor driving morphological

339 changes (Nakazato et al. 2008). Seeds are sensitive to changes in biotic and abiotic conditions

340 (Moles et al. 2005). According to Silvertown (1989), the correlation between seed size and the 
341 place where plant is growing is an adaptative feature. Bigger seeds occur in habitats with stable

342 environmental conditions, where seedlings may grow slowly. Small seeds are generally produced 343 by plants with a short life cycle, growing mainly in disturbed habitats.

344 Orange balsam is known for colonizing a wide range of habitats (Schemske 1978; Waller

345 1980). Moreover, Simpson et al. (1985) have shown that I. capensis vegetative and reproductive 346 growth parameters reflect habitat differences. Light availability (Simpson et al. 1985) as well as

347 soil moisture and $\mathrm{pH}$ (Waller 1980) have been reported to affect its growth patterns. Our studies

348 indicate that five environmental variables were statistically significant and were able to serve to

349 discern the studied populations in terms of seed size and weight: anthropogenic disturbances

350 (which may serve as a proxy for habitat fertility), carbonates $\left(\mathrm{CaCO}_{3}\right)$, loose sand presence,

351 potassium (K), and soil moisture (Fig. 4). Populations G (Police) and E (Święta), occurring in the

352 most disturbed anthropogenic habitats (artificial canal and roadside), have the heaviest seeds as a

353 result of growth under favorable environmental conditions (neutral or slightly acidic soil with a

354 relatively high $\mathrm{C} / \mathrm{N}$ ratio). In turn, population $\mathrm{B}$ (Lubin) with the smallest and lightest seeds was

355 associated with high soil $\mathrm{pH}$, and the highest content of soil carbonates and calcium.

356 Interestingly, Waller (1982) reported that the higher nodes of I. capensis individuals tended to

357 produce heavier seeds. In Waller's (1982) opinion, the position effect probably leads to a greater

358 mean seed size for higher plants. Werner and Platt (1976) stated that populations growing at

359 higher plant densities often produce larger seeds. Our results are consistent with both studies, as

360 the largest and heaviest seeds were obtained from populations G (Police) and E (Święta), formed

361 by the highest plants, growing in large numbers and densities.

362 Another important factor shaping a diverse array of plant traits, including morphological

363 features, is climate (Nakazato et al. 2008; Colautti, Barrett 2013; van Boheemen et al. 2019).

364 Temperature and precipitation gradients are the main climatic factors driving the adaptive

365 diversification of species (Nakazato et al. 2008). As it seems, climatic conditions have had a

366 limited effect on the investigated seed parameters till now, due to a small area of secondary

367 distribution of I. capensis in Poland (Adamowski et al. 2018; Fig. 1) and short time of residence

368 of little over 30 years. Although this investigated plant has only a few localities inhabiting only a

369 relatively small area in Poland, rapid expansion across environmental gradients has been

370 reported for several plants introduced to a new area and species can evolve quite quickly driven 
371 by environmental factors (Dlugosh, Parker 2008; Colautti, Barret 2013; Molina-Montenegro et 372 al. 2018; van Boheemen et al. 2019).

373 Phenotypic plasticity has been considered to be the primary feature enabling aliens to 374 colonize new, environmentally diverse areas (Richards et al. 2006; Molina-Montenegro et al. 375 2010). However, recent research has indicated that alien plants can evolve quickly in newly 376 occupied areas, so both phenotypic plasticity and evolution of reproductive features could be 377 relevant factors for successful invasions (Geng et al. 2007; Molina-Montenegro et al. 2018). An evolutionary explanation for plant invasiveness implies that seed and fruit traits are crucial for invasive plants since they are related to dispersal strategies and mechanisms to cope

380

381

382

383

384

385

386

387

388

389

390

391

392

393

394

395

396

397

398

399

400 with environmental stress. Some research reports have indicated that native and invasive populations employ different strategies for growth and reproduction (Chun et al. 2007; MolinaMontenegro et al. 2010, 2018). Results by Molina-Montenegro et al. (2018) suggest that some seed traits of invasive plant species with rapid adaptive capacity can evolve leading to maximizing their establishment in new environments and such features can be heritable.

Due to the scarcity of data we could not point out the presence of morphological differentiation between native and invasive populations of $I$. capensis, and we have not been able to determine whether the seed traits are evolving. However, I. capensis, classified as an invasive species in Poland, can be suspected, while adapting and occupying new territories and competing with native species, to develop specific adaptations, contributing to its success and spread in the new environments.

\section{Conclusions}

New data on seed morphology and seed coat sculpture of I. capensis is provided. The presented results are useful for the identification of this species when occurring together with other closely related species. These details on seed coat ornamentation are here described for the first time.

Further studies on the developmental variation of seed coat sculpture, especially of species closely related to I. capensis, may provide a better understanding of the evolutionary relationships of the different types of sculpture.

We provide new information on the plasticity of seeds of I. capensis. There are only few papers on the phenotypic variability of species of Impatiens. Data on the morphology of seeds 
401

402

403

404

405

406

407

408

409

410

411

412

413

414

415

416

417

418

419

420

421

422

423

424

425

426

427

428

429

430

can prove useful for determining the impact of various environmental factors on morphological traits and show whether a given feature is stable or susceptible to environmental change.

Our results suggest that certain habitat variables, especially anthropogenic disturbances and individual soil properties, contribute in shaping the morphological variation of seeds of $I$. capensis. In turn, the seed coat sculpture has turned out to be a stable feature within the secondary range of this species in Poland.

\section{Acknowledgments}

The authors wish to express their gratitude to Theodor C. H. Cole, Dipl. rer. nat. (FU Berlin) for English language editing and valuable comments.

\section{References}

\section{Abrahamczyk S, Lozada-Gobilard S, Ackermann M, Fischer E, Krieger V, Redling A,} Weigend M. 2017. A question of data quality - Testing pollination syndromes in Balsaminaceae. PLoS ONE 12(10):e0186125 DOI: 10.1371/journal.pone.0186125

Abrahamson WG, Hershey BJ. 1977. Resource allocation and growth of Impatiens capensis (Balsaminaceae) in two habitats. Bulletin of the Torrey Botanical Club 104:160-164

Adamowski W. 2016 onwards. Balsaminaceae Information Center. Available at: https://www.researchgate.net/project/Balsaminaceae-Information-Center (accessed 12 January 2020)

Adamowski W, Myśliwy M, Dajdok Z. 2018. Ankieta oceny stopnia inwazyjności Impatiens capensis Meerb. w Polsce, na podstawie protokołu Harmonia $+\mathrm{PL}$ - procedura oceny ryzyka negatywnego oddziaływania inwazyjnych i potencjalnie inwazyjnych gatunków obcych w Polsce. [Questionnaire for assessing the degree of invasiveness of Impatiens capensis Meerb. in Poland, based on the protocol Harmonia $+\mathrm{PL}$ - procedure for negative impact risk assessment for invasive alien species and potentially invasive alien species in Poland]. Generalna Dyrekcja Ochrony Środowiska. Available at http://projekty.gdos.gov.pl/igo (accessed 20 January 2020)

Akbari RS, Azizian D. 2006. Seed morphology and seed coat sculpturing of Epilobium L. species (Onagraceae Juss.) from Iran. Turkish Journal of Botany 30:435-440 
431

432

433

434

435

436

437

438

439

440

441

442

443

444

445

446

447

448

449

450

451

452

453

454

455

456

457

458

459

460

461

Akiyama S, Ohba H. 2000. Inflorescences of the Himalayan species of Impatiens (Balsaminaceae). Journal of Japanese Botany 75,4:226-240.

Antlfinger AE. 1989. Seed bank, survivorship and size distribution of a Nebraska population of Impatiens capensis (Balsaminaceae). American Journal of Botany 76,2:222-230.

Argyres A, Schmitt J. 1991. Microgeographic genetic structure of morphological and life history traits in a natural population of Impatiens capensis. Evolution 45:178-189.

Ballian D, Mujagić-Pašić A. 2013. Morphological variability of the fruit and seed of wild cherry (Prunus avium L.) in a part of its natural distribution in Bosnia and Herzegovina. Biologica Nyssana 4,1-2:15-17.

Barthlott W. 1981. Epidermal and seed surface characters of plants: systematic applicability and some evolutionary aspects. Nordic Journal of Botany. 1, 3: 345-355.

Bednarek R, Dziadowiec H, Pokojska U, Prusinkiewicz Z. 2011. Badania ekologicznogleboznawcze. Warszawa: WN PWN.

Bell G, Lechowicz MJ, Schoen DJ. 1991. The ecology and genetics of fitness in forest plants. III. Environmental variance in natural populations of Impatiens pallida. Journal of Ecology 79:697-714.

Bhaskar V. 2012. Taxonomic monograph on Impatiens L. (Balsaminaceae) of Western Ghats the key genus for endemism. Bangalore: Centre for Plant Taxonomic Studies.

Bojňanský V, Fargašová A. 2007. Atlas of seeds and fruits of Central and East-European flora. The Carpathian Mountains Region. Dordrecht: Springer.

Boyer MDH, Soper Gorden NL, Barber NA, Adler LS. 2016. Floral damage induces resistance to florivory in Impatiens capensis. Arthropod-Plant Interactions 10,2:121-131 DOI: $10.1007 / \mathrm{s} 11829-015-9411-\mathrm{y}$.

Cai X-Z, Yi R-Y, Zhuang Y-H, Cong Y-Y, Kuang R-P, Liu K-M. 2013. Seed coat micromorphology characteristics of Impatiens L. and its systematic significance. Acta Horticulturae Sinica 40,7:1337-1348.

Chen W, Liu K-M, Cai X-Z, Cong Y-Y. 2007a. Micromorphological features of seed surface of fourteen species in Impatiens (Balsaminaceae) in relation to their taxonomic significance. Acta Botanica Yunnanica 29,6:625-631.

Chen YL, Akiyama S, Ohba H. 2007b. Balsaminaceae. In: Wu ZY, Raven PH, eds. Flora of China. Beijing: Science Press; St. Louis: Missouri Botanical Garden Press. 12:43-113. 
462

463

464

465

466

467

468

469

470

471

472

473

474

475

476

477

478

479

480

481

482

483

484

485

486

487

488

489

490

491

492

Chmura D, Csontos P, Sendek A. 2013. Seed mass variation in Central European populations of invasive Impatiens glandulifera Royle. Polish Journal of Ecology 61,4:805-809.

Chun JJ, Michael L, Collyer ML, Kirk A, Moloney KA, Nason JD. 2007. Phenotypic plasticity of native vs. invasive purple loosestrife: a two-state multivariate approach. Ecology 88,6:1499-1512.

Colautti RI, Barrett SCH. 2013. Rapid adaptation to climate facilitates range expansion of an invasive plant. Science 342:364-366 DOI: 10.1126/science.1242121.

Constantinidis T, Psaras GK, Kamari G. 2001. Seed morphology in relation to infrageneric classification of Consolida (DC.) Gray (Ranunculaceae). Flora 196,2:81-100 DOI: 10.1016/S0367-2530(17)30024-5.

Day PD, Pellicer J, Kynast RG. 2012. Orange balsam (Impatiens capensis Meerb., Balsaminaceae): a re-evaluation by chromosome number and genome size. Journal of the Torrey Botanical Society 139,1:26-33 DOI: 10.2307/41475119.

Dlugosh KM, Parker IM. 2008. Founding events in species invasions: genetic variation, adaptive evolution, and the role of multiple introductions. Molecular Ecology 17:431-449 DOI: 10.1111/j.1365-294X.2007.03538.x.

Donohue K, Schmitt J. 1999. The genetic architecture of plasticity to density in Impatiens capensis. Evolution 53,5:1377-1386 DOI: 10.1111/j.1558-5646.1999.tb05402.x.

Donohue K, Hammond Pyle E, Messiqua D, Heschel MS, Schmitt J. 2000. Density dependence and population differentiation of genetic architecture in Impatiens capensis in natural environments. Evolution 54,6:1969-1981 DOI: 10.1111/j.00143820.2000.tb01241.x.

Euro+Med PlantBase. The information resource for Euro-Mediterranean plant diversity. Available at http://www.emplantbase.org/home.html (accessed 10 December 2019).

Ferreira T, Wayne R. 2010. The Image J User Guide. First edition: v 1.43 Available at http://imagej.nih.gov/ij/docs/guide/index.html\# (accessed 15 December 2019).

Gamarra R, Dorda E, Scrugli A, Galán P, Ortúñez E. 2007. Seed micromorphology in the genus Neotinea Rchb. f. (Orchidaceae, Orchidinae). Botanical Journal of the Linnean Society 153,2:133-140 DOI: 10.1111/j.1095-8339.2006.00603.x.

Gamarra R, Ortúñez E, Sanz E, Esparza I, Galán P. 2010. Seeds in subtribe Orchidinae (Orchidaceae): the best morphological tool to support molecular analyses. In: Nimis PL, 
493

494

495

496

497

498

499

500

501

502

503

504

505

506

507

508

509

510

511

512

513

514

515

516

517

518

519

520

521

522

Vignes Lebbe R. (eds.) Tools for Identifying Biodiversity: Progress and Problems, pp. 323-326.

Geng Y-P, Pan X-Y, Xu Ch-Y, Zhang W-J, Li B, Chen J-K, Lu B-R, Son Z-P. 2007.

Phenotypic plasticity rather than locally adapted ecotypes allows the invasive alligator weed to colonize a wide range of habitats. Biological Invasions 9:245-256 DOI: 10.1007/s10530-006-9029-1.

Gleason HA, Cronquist A. 1991. Manual of Vascular Plants of Northeastern United States and Adjacent Canada. Toronto, New York, London: Van Nostrand

Gogoi R, Borah S, Dash SS, Singh P. 2018. Balsams of Eastern Himalaya - A Regional Revision. Kolkata: Botanical Survey of India.

Grey-Wilson C. 1980. Impatiens of Africa: morphology; pollination and pollinators; ecology; phytogeography; hybridisation; keys and a systematic treatment of all African species; with a note on collecting and cultivation. Rotterdam: A. A. Balkema viii; 235p.

Hadidchi A, Attar F, Ullah F. 2020. Using microscopic techniques for taxonomic implications of seed and fruits of Delphinium L. (sensu lato) (Ranunculaceae). Microscopy Research and Technique 83,2:99-117 DOI: 10.1002/jemt.23393.

Hooker JD. 1904-1906. An epitome of the British Indian Species of Impatiens. Records of the Botanical Survey of India 4:1-58.

Hooker JD, Thomson T. 1859. Precursores ad floram indicam: Balsamineae. Journal of the Linnean Society 4:106-157.

Jacquemart AL, Somme L, Colin C, Quinet M. 2015. Floral biology and breeding system of Impatiens balfourii (Balsaminaceae): An exotic species in extension in temperate areas. Flora 214:70-75 DOI: 10.1016/j.flora.2015.06.001.

Janssens S, Geuten K, Viaene T, Yuan Y-M, Song Y, Smets E. 2007. Phylogenetic utility of the AP3/DEF K-domain and its molecular evolution in Impatiens (Balsaminaceae). Molecular Phylogenetics and Evolution 43,1:225-239 DOI: 10.1016/j.ympev.2006.11.016.

Janssens SB, Vinckier S, Bosselaers K, Smets EF, Huysmans S. 2018. Palynology of African Impatiens (Balsaminaceae). Palynology 43,4:621-630 DOI: 10.1080/01916122.2018.1509149. 
523 Jin XF, Yang SZ, Chen ZH, Quian L. 2008. Impatiens yilingiana sp. nov. and I.

524

525

526

527

528

529

530

531

532

533

534

535

536

537

538

539

540

541

542

543

544

545

546

547

548

549

550

551

552

553

huangyanensis subsp. attenuata subsp. nov. (Balsaminaceae) from Zhejiang, eastern

China. Nordic Journal of Botany 26,3-4:207-213 DOI: 10.1111/j.17561051.2008.00325.x.

Jongman RHG, ter Braak CJF, van Tongeren OFR, eds. 1995. Data analysis in community and landscape ecology. Cambridge (UK): Cambridge University Press.

Kovach WL. 2010. MVSP - A MultiVariate Statistical Package for Windows, ver. 3.2. Pentraeth, Wales (UK): Kovach Computing Services.

Lepš J, Šmilauer P. 2003. Multivariate analysis of ecological data using CANOCO. Cambridge: Cambridge University Press.

Lu Y-Q, Chen Y-L. 1991. Seed morphology of Impatiens L. (Balsaminaceae) and its taxonomic significance. Acta Phytotaxonomica Sinica 29:252-257.

Maciejewska-Rutkowska I, Janczak B. 2016. Variability of seeds of the invasive species Impatiens glandulifera Royle (Balsaminaceae) and their micromorphology. Steciana 20,4:183-190 DOI: 10.12657/steciana.020.019.

Martín-Gómez JJ, Rewicz A, Cervantes E. 2019a. Seed Shape Diversity in families of the Order Ranunculales. Phytotaxa 425,4:193-207 DOI: 10.11646/phytotaxa.425.4.1.

Martín-Gómez JJ, Rewicz A, Goriewa-Duba K, Wiwart M, Tocino Á, Cervantes E. $2019 b$. Morphological description and classification of wheat kernels based on geometric models. Agronomy 9,7:399 DOI:10.3390/agronomy9070399.

Matthews J, Beringen R, Boer E, Duistermaat H, Odé B, van Valkenburg JLCH, van der Velde G, Leuven RSEW. 2015. Risks and management of non-native Impatiens species in the Netherlands. Radboud University, FLORON, Naturalis Biodiversity Center, The Netherlands. Available at http://repository.ubn.ru.nl/handle/2066/149286 (accessed 12 December 2019).

Meissner W. 2010. Przewodnik do ćwiczeń z przedmiotu metody statystyczne $w$ biologii. Gdańsk: Wydawnictwo Uniwersytetu Gdańskiego.

Meusel H, Jager E, Rauschert S, Weinert E. 1978. Vergleichende Chorologie der Zentraleuropäischen Flora 2. Jena: Gustav Fischer Verl.

Moles AT, Ackerly DD, Webb CO, Tweddle JC, Dickie JB, Pitman AJ, Westoby M. 2005. Factors that shape seed mass evolution. PNAS 102,30:10540-10544.

Peer] reviewing PDF | (2020:02:45912:3:0:NEW 9 Sep 2020) 
554

555

556

557

558

559

560

561

562

563

564

565

566

567

568

569

570

571

572

573

574

575

576

577

578

579

580

581

582

583

Molina-Montenegro MA, Acuña-Rodríguez IS, Flores TSM, Hereme R, Lafon A, Atala C, Torres-Díaz C. 2018. Is the success of plant invasions the result of rapid adaptive evolution in seed traits? Evidence from a latitudinal rainfall gradient. Frontiers In Plant Science 9:208 DOI: 10.3389/fpls.2018.00208.

Molina-Montenegro MA, Atala C, Gianoli E. 2010. Phenotypic plasticity and performance of Taraxacum officinale (dandelion) in habitats of contrasting environmental heterogeneity. Biological Invasions 12:2277-2284. DOI: 10.1007/s10530-009-9638-6.

Moore DM. 1968. Impatiens L. In: Tutin TG, Heywood VH, Burges NA, Moore DM, Valentine DH, Walters SM, Webb DA, eds. Flora Europaea. Cambridge: Cambridge Univ. Press. 2:240-242.

Myśliwy M. 2019. Diversity and environmental variability of riparian tall herb fringe communities of the order Convolvuletalia sepium in Polish river valleys. Wrocław: Polish Botanical Society. Monographiae Botanicae 108 DOI: 10.5586/mb.2019.001.

Myśliwy M, Ciaciura M, Hryniewicz M. 2009. Charakterystyka populacji Impatiens capensis Meerb. nad Zalewem Szczecińskim. In: Ciaciura M, ed. Flora roślin naczyniowych województwa zachodniopomorskiego. Cz. II: 225-246. Szczecin: Katedra Taksonomii Roślin i Fitogeografii Uniwersytetu Szczecińskiego.

Nakazato T, Bogonovich M, Moyle LC. 2008. Environmental factors predict adaptive phenotypic differentiation within and between two wild Andean tomatoes. Evolution 62,4: 774-792 DOI:10.1111/j.1558-5646.2008.00332.x.

Nanda KK, Kumar S. 1983. Some spectacular responses of flowering in Impatiens balsamina L. cv. Rose. Current Science 52:571-576.

Pawlaczyk P, Adamowski W. 1991. Impatiens capensis (Balsaminaceae) - nowy gatunek we florze Polski. Fragmenta Floristica et Geobotanica 35:225-232.

Popiela A, Lysko A, Sotek Z, Ziarnek K. 2015. Preliminary results of studies on the distribution of invasive alien vascular plant species occurring in semi-natural and natural habitats in NW Poland. Biodiversity: Research and Conservation 37:21-35 DOI: 10.1515/biorc-2015-0003.

PSSS 2009. Particle size distribution and textural classes of soils and mineral materials classification of Polish Society of Soil Science 2008. Roczniki Gleboznawcze 60,2:5-16. 
584 Rahelivololona EM, Fischer E, Janssens SB, Razafimandimbison SG. 2018. Phylogeny, 585 infrageneric classification and species delimitation in the Malagasy Impatiens 586 (Balsaminaceae). PhytoKeys 110:51-67 DOI: 10.3897/phytokeys.110.28216.

587 Rewicz A, Bomanowska A, Magda J, Rewicz T. 2017. Morphological variability of Consolida 588 regalis seeds of south-eastern and central Europe. Systematics and Biodiversity 15,1:25589 590 591 592 593 594 595 596 597 598 599 600 601 602 603 604 605 606 607 608 609 610 611 34 DOI: $10.1080 / 14772000.2016 .1216017$

Rewicz A, Kolodziejek J, Jakubska-Busse A. 2016. The role of anthropogenic habitats as substitutes for natural habitats: a case study on Epipactis helleborine (L.) Crantz (Orchidaceae, Neottieae). Variations in size and nutrient composition of seed. Turkish Journal of Botany 40,3:258-268.

Richards CL, Bossdorf O, Muth NZ, Gurevith J, Pigliucci M. 2006. Jack of all trades, master of some? On the role of phenotypic plasticity in plant invasions. Ecological Letters 9:981-993 DOI: 10.1111/j.1461-0248.2006.00950.x.

Ruchisansakun S, van der Niet T, Janssens SB, Triboun P, Techaprasan J, Jenjittikul T, Suksathan P. 2015. Phylogenetic analyses of molecular data and reconstruction of morphological character evolution in Asian Impatiens Section Semeiocardium (Balsaminaceae). Systematic Botany 40,4:1063-1074 DOI: 10.1600/036364415X690102.

Ruchisansakun S, Suksathan P, van der Niet T, Smets EF, Saw-Lwin, Janssens SB. 2018. Balsaminaceae of Myanmar. Blumea 63:199-267 DOI: 10.3767/blumea.2018.63.03.01.

Rust RW. 1977. Pollination in Impatiens capensis and Impatiens pallida (Balsaminaceae). Bulletin of Torrey Botanical Club 104:361-367.

Schemske DW. 1978. Evolution of reproductive characteristics in Impatiens (Balsaminaceae): the significance of cleistogamy and chasmogamy. Ecology 59:596-613.

Schmitt J. 1993. Reaction norms of morphological and life-history traits to light availability in Impatiens capensis. Evolution 47,6:1654-1668.

Schmitt J, Ehrhardt DW, Swartz D. 1985. Differential dispersal of self-fertilized and outcrossed progeny in jewelweed (Impatiens capensis). American Naturalist 126:570575.

Shimizu T. 1977. Some additional notes on Impatiens (Balsaminaceae) of Thailand. Acta Phytotaxonomica et Geobotanica 28:31-34. 
614 Shimizu T. 1979. A comment on the limestone flora of Thailand, with special reference to 615 Impatiens. Acta Phytotaxonomica et Geobotanica 30:180-188.

616 Shui Y-M, Janssens S, Huang S-H, Chen W-H, Yang Z-G. 2011. Three new species of 617 Impatiens L. from China and Vietnam: preparation of flowers and morphology of pollen 618 619 620 and seeds. Systematic Botany 36,2:428-439 DOI: 10.1600/036364411X569615.

Silvertown J. 1989. The paradox of seed size and adaptation. Trends in Ecology and Evolution 4:24-26.

Simpson RL, Leck MA, Parker TV. 1985. The comparative ecology of Impatiens capensis Meerb. (Balsaminaceae) in central New Jersey. Bulletin of Torrey Botanical Club 112:295-311.

Soil Science Society of Poland. 2017. Fieldguide for soil description. Warszawa: Polskie Towarzystwo Gleboznawcze.

Song Y, Yuan Y-M, Kupfer P. 2005. Seed coat micromorphology of Impatiens (Balsaminaceae) from China. Botanical Journal of the Linnean Society 149:195-208.

Sreelakshmi V, Prabhu Ramya R, Arya VK, Athira VM, Ayeasha M, Shaninas S, Subhandra Vishnu C. 2018. Phytochemical screening and evaluation of antioxidant potential of Impatiens balsamina L. flowers in vitro. Trends in Biosciences 11:14121416.

Stace CA. 1992. Plant Taxonomy and Biosystematics. Cambridge: Cambridge University Press. StatSoft Inc. 2011. STATISTICA (data analysis software system), version 13.1. Available at www.statsoft.com (accessed 10 December 2019).

Tabak NM, von Wettberg E. 2008. Native and introduced jewelweeds of the Northeast. Northeastern Naturalist 15:159-176.

Tantaway M, Sayed F, Soad A, Ghalia T. 2004. Seed exomorphic characters of some Brassicaceae (LM and SEM study). International Journal of Agriculture and Biology 1560:821-830.

ter Braak CJF, Šmilauer P. 2002. CANOCO Reference manual and CanoDraw for Windows User's guide: Software for Canonical Community Ordination (version 4.5). Ithaca, NY, USA: Microcomputer Power. 
643 Tokarska-Guzik B, Dajdok Z, Zając M, Zając A, Urbisz A, Danielewicz W, Hołdyński C.

644

645

646

647

648

649

650

651

652

653

654

655

656

657

658

659

660

661

662

663

664

665

666

667

668

669

670

671 2012. Rośliny obcego pochodzenia w Polsce ze szczególnym uwzględnieniem gatunków inwazyjnych. Warszawa: Generalna Dyrekcja Ochrony Środowiska.

Tooke F, Ordidge M, Chiurugwi T, Battey N. 2005. Mechanisms and function of flower and inflorescence reversion. Journal of Experimental Botany 56:2587-2599.

Ullah F, Papini A, Shah SN, Zaman W, Sohail A, Iqbal M. 2019a. Seed micromorphology and its taxonomic evidence in subfamily Alsinoideae (Caryophyllaceae). Microscopy Research and Technique 82:250-259 DOI: 10.1002/jemt.23167.

Ullah F, Zaman W, Papini A, Zafar M, Shah S N, Ahmad M, Saqib S, Gul S, Sohail A. 2019b. Using multiple microscopic techniques for the comparative systematic of Spergula fallax and Spergula arvensis (Caryophyllaceae). Microscopy Research and Technique 82:352-360 DOI: 10.1002/jemt.23176.

Utami N, Shimizu T. 2005. Seed morphology and classification of Impatiens (Balsaminaceae). Blumea 50:447-456.

van Boheemen LA, Atwater DZ, Hodgins KA. 2019. Rapid and repeated local adaptation to climate in an invasive plant. New Phytologist 222:614-627.

van Emden H. 2008. Statistics for terrified biologists. USA, UK, Australia: Blackwell Publishing.

Waller D. 1980. Environmental determinants of outcrossing in Impatiens capensis (Balsaminaceae). Evolution 34:747-761.

Waller DM. 1982. Factors influencing seed weight in Impatiens capensis (Balsaminaceae). American Journal of Botany 69,9:1470-1475.

Warburg O, Reiche K. 1895. Balsaminaceae. In: Engler A, Prantl K, eds. Die natürlichen Pflanzenfamilien 3:390-392. Leipzig: Engelmann.

Werner FA, Platt WJ. 1976. Ecological relationships of co-occurring goldenrods (Solidago: Compositae). The American Naturalist 110:959-971.

Więcław H, Kurnicki B, Bihun M, Białecka B, Koopman J. 2017. Carex section Racemosae (Cyperaceae) in Europe: morphological diversity, taxonomy and phylogenetic relationships. Botanical Journal of the Linnean Society 183:124-145. 
672 Xia C-Y, Gadagkar SR, Zhao X-L, Van Do Truong, Zhu X-Y, Qin Y, Deng HP, Yu S-X.

673

674

675

676

677

678

679

680

681

682

683

684

685

686

687

688

689

690

691

692

693

694

695

696

697

698

699

700

701

702 2019. Impatiens maculifera sp. nov. (Balsaminaceae) Yunnan, China. Nordic Journal of Botany 2019:e02422 DOI: 10.1111/njb.02422

Yu SX. 2012. Balsaminaceae of China. Beijing: Peking University Press.

Yu S-X, Chen Y-L, Qin H-N. 2007. Impatiens macrovexilla var. yaoshanensis S. X. Yu, Y. L. Chen \& H. N. Qin, a new variety of Balsaminaceae from Guangxi, China. Acta Phytotaxonomica Sinica 45(5):708-712. DOI: 10.1360/aps06037

Yu SX, Janssens SB, Zhu XY, Lidén M, Gao TG, Wang W. 2015. Phylogeny of Impatiens (Balsaminaceae): integrating molecular and morphological evidence into a new classification. Cladistics 32:179-197 DOI: 10.1111/cla.12119

Yuan Y-M, Song Y, Geuten K, Rahelivololona E, Wohlhauser S, Fischer E, Smets E, Küpfer P. 2004. Phylogeny and biogeography of Balsaminaceae inferred from ITS sequences. Taxon 53(2):391-403

Zar JH. 1984. Biostatistical analysis. 2nd edn. Englewood Cliffs: Prentice-Hall, Inc. 718.

Zhang LJ, Guo H, Li XH, Liang TJ, Zhang M, Yu SX. 2016. Observation research of the seedcoat micromorphology of Impatiens sect. Racemasae. Acta Horticulturae Sinica 40:1337-1348 DOI: 10.16420/j.issn.0513-353x.2016-0097

Zhou L, Tian J, Wu Y, Li S, Wu Y, Kuang R, Liu K, Liu K. 2019. Newly recorded plants from Hunan Province of China (VIII). Life Science Research 23:35-38 DOI: 10.16605/j.cnki.1007-7847.2019.01.005

Zika PF. 2006. The status of Impatiens capensis (Balsaminaceae) on the Pacific Northwest coast. The Journal of the Torrey Botanical Society 133,4:593-600 DOI: 10.3159/10955674(2006)133[593:TSOICB]2.0.CO;2

Zika PF. 2009. Impatiens of the Pacific Northwest. Available at http://bomi.ou.edu/ben/408/impatiens_figures_408.pdf(accessed 10 January 2020).

Acknowledgments

The authors wish to express their gratitude to Theodor C. H. Cole, Dipl. rer. nat. (FU Berlin) for English language editing and valuable comments. 


\section{Table $\mathbf{1}$ (on next page)}

List of the studied populations of Impatiens capensis Meerb. in Poland. 
1

\begin{tabular}{|c|c|c|c|c|c|c|c|}
\hline Code & Locality & Latitude & Longitude & Habitat & $\begin{array}{c}\text { Average } \\
\text { plant } \\
\text { height }[\mathrm{cm}]\end{array}$ & $\begin{array}{c}\text { Number of } \\
\text { analyzed } \\
\text { seeds }\end{array}$ & $\begin{array}{c}\text { Population size } \\
\text { (mature } \\
\text { individuals) }\end{array}$ \\
\hline A & Podgrodzie & $53.740222^{\circ}$ & $14.306667^{\circ}$ & $\begin{array}{l}\text { tall herbs on } \\
\text { the bank of } \\
\text { Szczecin }\end{array}$ & 130 & 29 & $20-30$ \\
\hline B & Lubin & $53.865056^{\circ}$ & $14.426778^{\circ}$ & $\begin{array}{l}\text { Lagoon } \\
\text { tall herbs and } \\
\text { grasses near } \\
\text { water seeps }\end{array}$ & 50 & 24 & $>20$ \\
\hline $\mathrm{C}$ & Unin & $53.894806^{\circ}$ & $14.634444^{\circ}$ & $\begin{array}{l}\text { tall herbs } \\
\text { along the river }\end{array}$ & 120 & 27 & $20-30$ \\
\hline D & Czarnocin & $53.722306^{\circ}$ & $14.549167^{\circ}$ & $\begin{array}{l}\text { tall herbs on } \\
\text { the bank of } \\
\text { Szczecin } \\
\text { Lagoon }\end{array}$ & 130 & 30 & $>50$ \\
\hline E & Święta & $53.559861^{\circ}$ & $14.659083^{\circ}$ & $\begin{array}{l}\text { tall herbs } \\
\text { along } \\
\text { roadside ditch }\end{array}$ & 165 & 27 & $>100$ \\
\hline $\mathrm{F}$ & $\begin{array}{l}\text { Szczecin- } \\
\text { Zdroje }\end{array}$ & $53.382861^{\circ}$ & $14.614944^{\circ}$ & $\begin{array}{l}\text { tall herbs } \\
\text { along the river }\end{array}$ & 120 & 29 & $>50$ \\
\hline G & Police & $53.573194^{\circ}$ & $14.581472^{\circ}$ & $\begin{array}{l}\text { willow forest } \\
\text { along } \\
\text { artificial canal }\end{array}$ & 145 & 28 & $>100+$ \\
\hline $\mathrm{H}$ & Trzebieradz & $53.675417^{\circ}$ & $14.441444^{\circ}$ & alder carr & 70 & 30 & $>100+$ \\
\hline
\end{tabular}

2 


\section{Table 2 (on next page)}

Biometric comparison of seed traits of Impatiens capensis Meerb.

Seed length (SL), seed width (SW), seed circumference $(\mathrm{SC})$, seed area (SA), variation coefficient CV), standard deviation (SD), minimum/maximum (Min/Max), arithmetic average $(\mathrm{x}), \mathrm{A}-\mathrm{H}$ as in Table 1. 
1

\begin{tabular}{llllllllll}
\hline & $\mathrm{A}$ & $\mathrm{B}$ & $\mathrm{C}$ & $\mathrm{D}$ & $\mathrm{E}$ & $\mathrm{F}$ & $\mathrm{G}$ & $\mathrm{H}$ & $\mathrm{x}$ \\
\hline Weight (mg) & 7.66 & 6.52 & 8.16 & 7.82 & 9.82 & 8.62 & $\mathbf{1 1 . 4 2}$ & 6.92 & 8.37 \\
\hline SL (mm) & 4.05 & 3.88 & 4.23 & 4.11 & 4.46 & 4.17 & $\mathbf{4 . 6 0}$ & 4.41 & 4.24 \\
Min-max & $3.50-$ & $3.16-$ & $3.68-$ & $3.59-$ & $3.85-$ & $3.43-$ & $3.88-$ & $3.59-$ & $3.16-$ \\
& 4.64 & 4.48 & 4.70 & 4.75 & 5.26 & 4.73 & 5.74 & 4.82 & 5.74 \\
SD & 0.26 & 0.40 & 0.29 & 0.30 & 0.32 & 0.40 & 0.40 & 0.27 & 0.40 \\
CV & 6.50 & 10.28 & 6.95 & 7.35 & 7.21 & 9.71 & 8.75 & 6.19 & 9.34 \\
\hline SW (mm) & 2.23 & 2.03 & 2.36 & 2.56 & 2.60 & 2.40 & $\mathbf{2 . 7 1}$ & 2.23 & 2.39 \\
Min-max & $1.53-$ & $1.12-$ & $1.78-$ & $2.14-$ & $2.19-$ & $1.88-$ & $2.15-$ & $1.71-$ & $1.12-$ \\
& 2.82 & 2.61 & 3.00 & 2.94 & 3.33 & 2.99 & 3.21 & 2.93 & 3.33 \\
SD & 0.28 & 0.42 & 0.33 & 0.19 & 0.31 & 0.32 & 0.30 & 0.30 & 0.37 \\
CV & 12.50 & 20.57 & 13.98 & 7.30 & 12.02 & 13.19 & 11.04 & 13.51 & $\mathbf{1 5 . 3 5}$ \\
\hline SC (mm) & 10.00 & 9.55 & 10.51 & 10.61 & 11.21 & 10.49 & $\mathbf{1 1 . 6 5}$ & 10.75 & 10.61 \\
Min-max & $8.63-$ & $7.27-$ & $9.13-$ & $9.35-$ & $9.77-$ & $8.61-$ & $10.17-$ & $8.9-$ & $7.27-$ \\
& 11.94 & 10.98 & 11.70 & 12.70 & 13.27 & 12.10 & 14.59 & 12.20 & 14.59 \\
SD & 0.77 & 1.09 & 0.67 & 0.69 & 0.89 & 0.89 & 1.04 & 0.67 & 1.02 \\
CV & 7.65 & 11.42 & 6.39 & 6.50 & 7.90 & 8.53 & 8.97 & 6.22 & 9.64 \\
\hline SA (mm $\left.{ }^{2}\right)$ & 6.52 & 5.79 & 7.15 & 7.71 & 8.42 & 6.74 & $\mathbf{9 . 2 6}$ & 7.25 & 7.44 \\
Min-max & $4.72-$ & $2.43-$ & $5.10-$ & $5.83-$ & $6.15-$ & $4.82-$ & $6.74-$ & $5.27-$ & $2.43-$ \\
CV & 9.53 & 7.69 & 9.10 & 1.23 & 12.16 & 1.21 & 13.54 & 9.61 & 13.54 \\
\hline & 1.14 & 1.51 & 1.21 & 1.07 & 1.48 & 1.27 & 1.63 & 1.08 & 1.62 \\
& 17.54 & 26.06 & 16.92 & 13.88 & 17.63 & 17.58 & 17.65 & 14.96 & $\mathbf{2 1 . 7 6}$ \\
\hline & & & & & & & & & \\
& & & & & & &
\end{tabular}

2 


\section{Table 3 (on next page)}

Spearman correlation values for seed traits of Impatiens capensis Meerb. All values with significance of $p<0.05$. 
1

\begin{tabular}{l|llll}
\hline & Length & Width & Circumference & Area \\
\hline Length & 1.00 & 0.47 & 0.85 & 0.72 \\
Width & & 1.00 & 0.73 & 0.84 \\
Circumference & & & 1.00 & 0.94 \\
Area & & & & 1.00 \\
\hline
\end{tabular}

2 


\section{Table 4 (on next page)}

Interpopulation variability for length (A), width (B), circumference (C), and area (D) of seeds of Impatiens capensis. Asterisk next to letter indicates significance at $p<0.05$. 
1

\begin{tabular}{|c|c|c|c|c|c|c|c|c|}
\hline & Podgrodzie & Lubin & Unin & Czarnocin & Święta & $\begin{array}{l}\text { Szczecin- } \\
\text { Zdroje }\end{array}$ & Police & Trzebieradz \\
\hline Podgrodzie & & $\mathrm{ABCD}$ & $\mathrm{ABCD}$ & $\mathrm{AB}^{*} \mathrm{CD}^{*}$ & $\mathrm{~A} * \mathrm{~B} * \mathrm{C} * \mathrm{D} *$ & $\mathrm{ABCD}$ & $\mathrm{A}^{*} \mathrm{~B}^{*} \mathrm{C}^{*} \mathrm{D}^{*}$ & $\mathrm{~A}^{*} \mathrm{BC} * \mathrm{D}$ \\
\hline Lubin & & & $\mathrm{ABCD}$ & $A B^{*} C^{*} D^{*}$ & $A^{*} B^{*} C^{*} D^{*}$ & $\mathrm{AB}^{*} \mathrm{CD}$ & $A * B * C * D *$ & $\mathrm{~A} * \mathrm{BC} * \mathrm{D}$ \\
\hline Unin & & & & $\mathrm{ABCD}$ & $\mathrm{ABCD}$ & $\mathrm{ABCD}$ & $A * B^{*} C^{*} D^{*}$ & $\mathrm{ABCD}$ \\
\hline Czarnocin & & & & & $\mathrm{A} * \mathrm{BCD}$ & $\mathrm{ABCD}$ & $\mathrm{A} * \mathrm{BC} * \mathrm{D}$ & $A * B * C D$ \\
\hline Święta & & & & & & $\mathrm{ABCD}$ & $\mathrm{ABCD}$ & $A B * C D$ \\
\hline Szczecin- & & & & & & & $A * B C * D^{*}$ & $\mathrm{ABCD}$ \\
\hline Zdroje & & & & & & & & \\
\hline Police & & & & & & & & $\mathrm{AB} * \mathrm{CD}^{*}$ \\
\hline Trzebieradz & & & & & & & & \\
\hline
\end{tabular}




\section{Table 5 (on next page)}

Seed roundness (R) comparison between populations of Impatiens capensis Meerb. in Poland.

Explanation: SD - standard deviation, A-H - in Table 1; the same capital letters mean the values do not differ significantly 
1

\begin{tabular}{l|llllllllll}
\hline & $\mathrm{R}$ & $\mathrm{SD}$ & $\mathrm{A}$ & $\mathrm{B}$ & $\mathrm{C}$ & $\mathrm{D}$ & $\mathrm{E}$ & $\mathrm{F}$ & $\mathrm{G}$ & $\mathrm{H}$ \\
\hline $\mathrm{A}$ & 0.50 & 0.06 & $\mathrm{a}$ & $\mathrm{a}$ & $\mathrm{a}$ & $p=0.0023$ & $\mathrm{a}$ & $\mathrm{a}$ & $\mathrm{a}$ & $\mathrm{a}$ \\
$\mathrm{B}$ & 0.48 & 0.08 & & $\mathrm{a}$ & $\mathrm{a}$ & $p=0.0000$ & $\mathrm{a}$ & & $p=0.0087$ & $\mathrm{a}$ \\
$\mathrm{C}$ & 0.51 & 0.09 & & & & $p=0.0033$ & $\mathrm{a}$ & $\mathrm{a}$ & $\mathrm{a}$ & $\mathrm{a}$ \\
$\mathrm{D}$ & 0.58 & 0.06 & & & & $\mathrm{a}$ & $\mathrm{a}$ & $\mathrm{a}$ & $p=0.0000$ \\
$\mathrm{E}$ & 0.54 & 0.07 & & & & & $\mathrm{a}$ & $\mathrm{a}$ & $p=0.0197$ \\
$\mathrm{~F}$ & 0.53 & 0.07 & & & & & & $\mathrm{a}$ & $\mathrm{a}$ \\
$\mathrm{G}$ & 0.56 & 0.07 & & & & & & & & $p=0.0002$ \\
$\mathrm{H}$ & 0.47 & 0.05 & & & & & & & & \\
\hline
\end{tabular}

2

3 


\section{Table 6(on next page)}

Soil conditions at the investigated sites of occurrence of Impatiens capensis Meerb. in Poland.

Explanation: LoSa, loose sand; LSa, loamy sand; SLSa, slightly loamy sand; Org, organic soil; LOI, organic matter content; $\mathrm{C}_{\text {org, }}$ organic carbon; $\mathrm{N}_{\text {tot }}$, total nitrogen; $\mathrm{C} / \mathrm{N}, \mathrm{C} / \mathrm{N}$ ratio; $\mathrm{pH}$, soil $\mathrm{pH} ; \mathrm{CaCO}_{3}$, carbonates; Ca, calcium; $\mathrm{P}$, phosphorus; $\mathrm{K}$, potassium; Mg, magnesium; $\mathrm{Na}$, sodium; Moist, soil moisture content. 
1

\begin{tabular}{l|lllllllllllll}
\hline $\begin{array}{l}\text { Code/ } \\
\text { Locality }\end{array}$ & $\begin{array}{l}\text { Soil } \\
\text { group }\end{array}$ & LOI & $\mathrm{C}_{\text {org }}$ & $\mathrm{N}_{\text {tot }}$ & $\mathrm{C} / \mathrm{N}$ & $\mathrm{pH}$ & $\mathrm{CaCO}_{3}$ & $\mathrm{Ca}$ & $\mathrm{P}$ & $\mathrm{K}$ & $\mathrm{Mg}$ & $\mathrm{Na}$ & Moist \\
\hline $\mathrm{A}$ & $\mathrm{LoSa}$ & 11.6 & 7.11 & 0.52 & 13.61 & 6.6 & 0.00 & 3007 & 60.2 & 68.3 & 378.0 & 405.4 & 3 \\
$\mathrm{~B}$ & $\mathrm{LSa}$ & 15.8 & 9.98 & 0.65 & 15.37 & 7.4 & 3.54 & 30769 & 194.5 & 171.8 & 258.0 & 181.6 & 2 \\
$\mathrm{C}$ & $\mathrm{LSa}$ & 23.4 & 12.63 & 0.95 & 13.25 & 7.3 & 2.31 & 18476 & 130.4 & 206.4 & 325.0 & 177.9 & 3 \\
$\mathrm{D}$ & $\mathrm{Org}$ & 65.3 & 31.90 & 2.54 & 12.54 & 6.7 & 1.47 & 21816 & 653.6 & 310.0 & 1796.0 & 1152.8 & 3 \\
$\mathrm{E}$ & $\mathrm{LoSa}$ & 19.5 & 13.18 & 0.81 & 16.25 & 6.3 & 0.00 & 9142 & 67.6 & 187.9 & 204.0 & 62.2 & 2 \\
$\mathrm{~F}$ & $\mathrm{SLSa}$ & 6.0 & 3.70 & 0.27 & 13.49 & 7.5 & 1.09 & 5792 & 111.6 & 85.9 & 89.0 & 44.0 & 3 \\
$\mathrm{G}$ & $\mathrm{LSa}$ & 17.3 & 8.77 & 0.55 & 15.84 & 6.8 & 0.00 & 7801 & 117.7 & 47.4 & 264.0 & 638.5 & 2 \\
$\mathrm{H}$ & $\mathrm{LoSa}$ & 16.5 & 7.95 & 0.43 & 18.69 & 5.1 & 0.00 & 2705 & 31.4 & 33.7 & 262.0 & 57.6 & 4 \\
\hline
\end{tabular}

2 


\section{Figure 1}

Distribution map of Impatiens capensis Meerb. in Europe (C), range in Poland (B), sites of the studied populations (A) (prepared by Adamowski \& Myśliwy). Satellite map data (c)2019 Google, Modifed using CorelDRAW 18 . Explanation of symbols see Table

Satellite map data (C2019 Google, Modifed using CorelDRAW 18 . Explanation of symbols see Table 1.

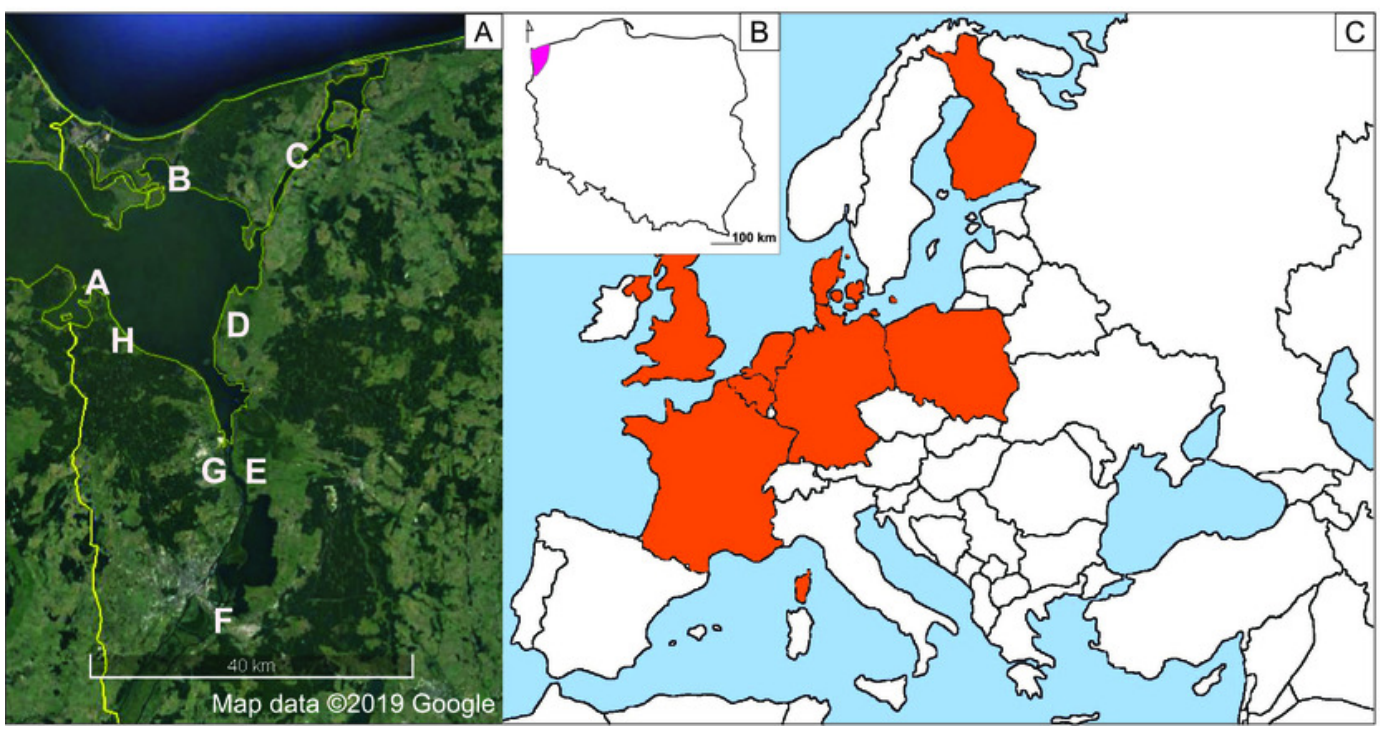


Figure 2

Ranges of variation of seed traits of Impatiens capensis Meerb.

The boxes represent the 25th-75th percentiles; the upper and lower whiskers extend the minimum and maximum data point; the square inside the box indicates median. A: seed length (SL); B: seed width (SW); C: seed circumference (SC); D: seed area (SA).
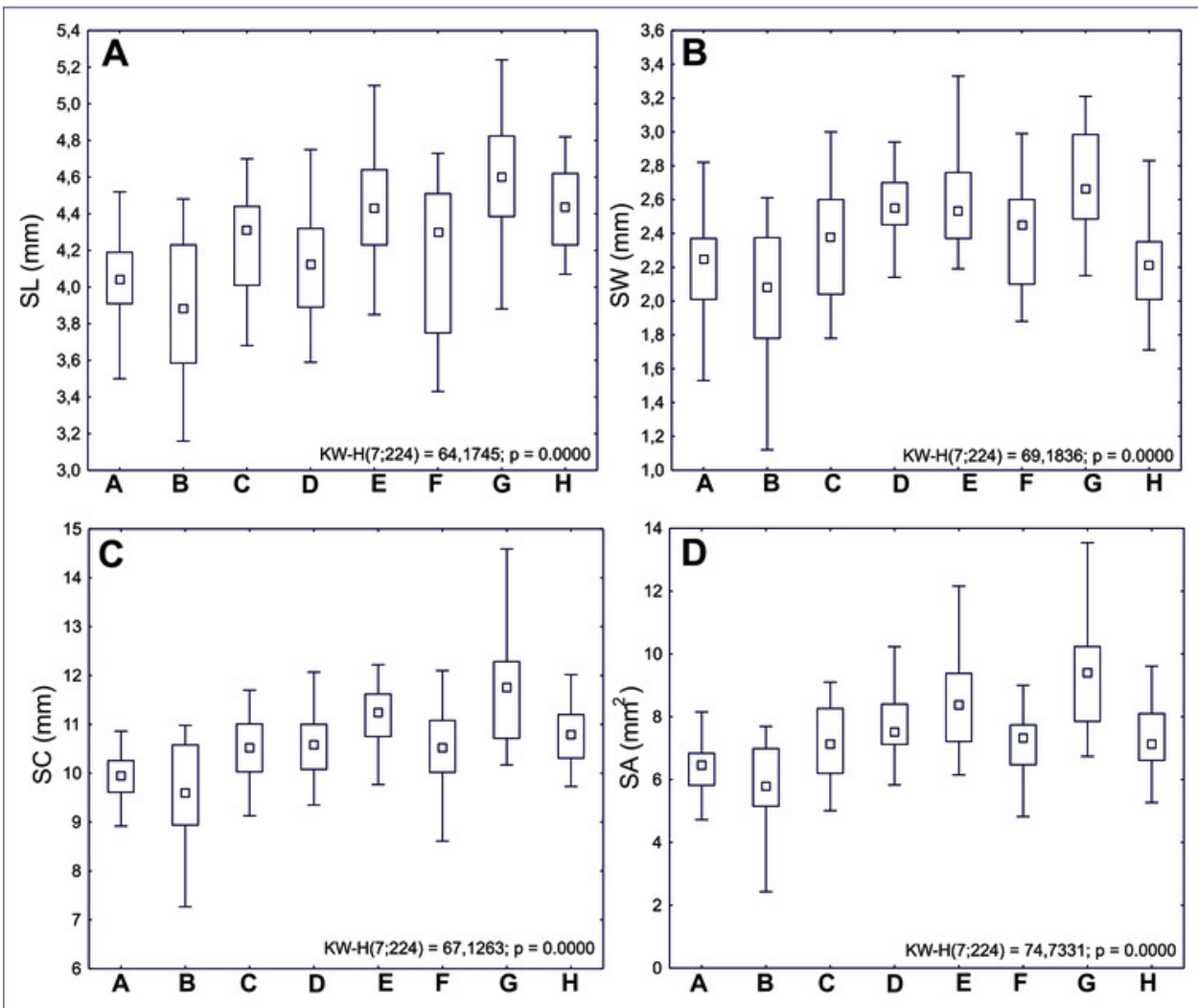
Figure 3

Dendrogram of similarities of populations of Impatiens capensis Meerb. in Poland, obtained by the nearest neighbor method.

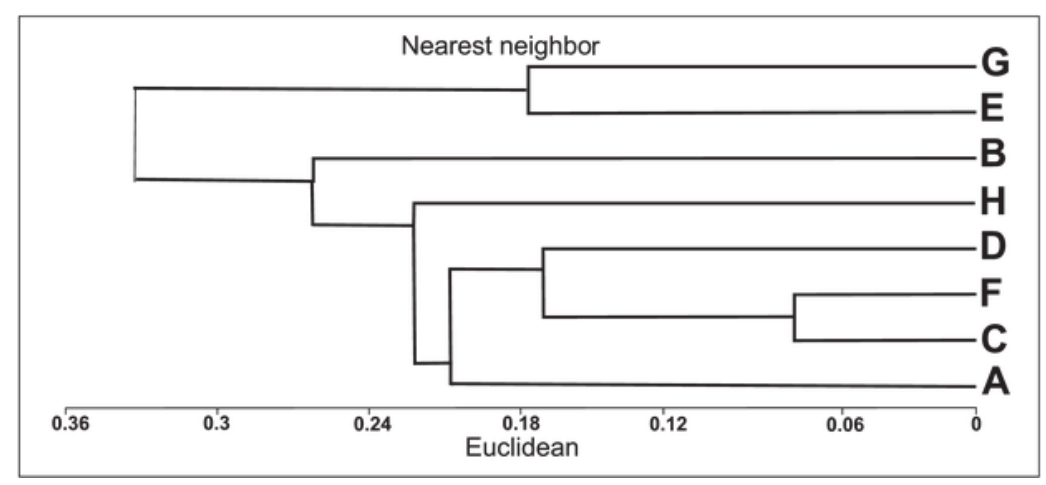




\section{Figure 4}

Ordination diagram of populations of Impatiens capensis Meerb.

(A-H), seed biometric traits (dotted gray arrows) and environmental variables (solid black arrows) along the first two RDA axes. * Statistically significant variables; Anthrop, anthropogenic disturbances; Shadow, degree of shading. For codes of populations and soil properties see Tables 1 and 6 , respectively. 


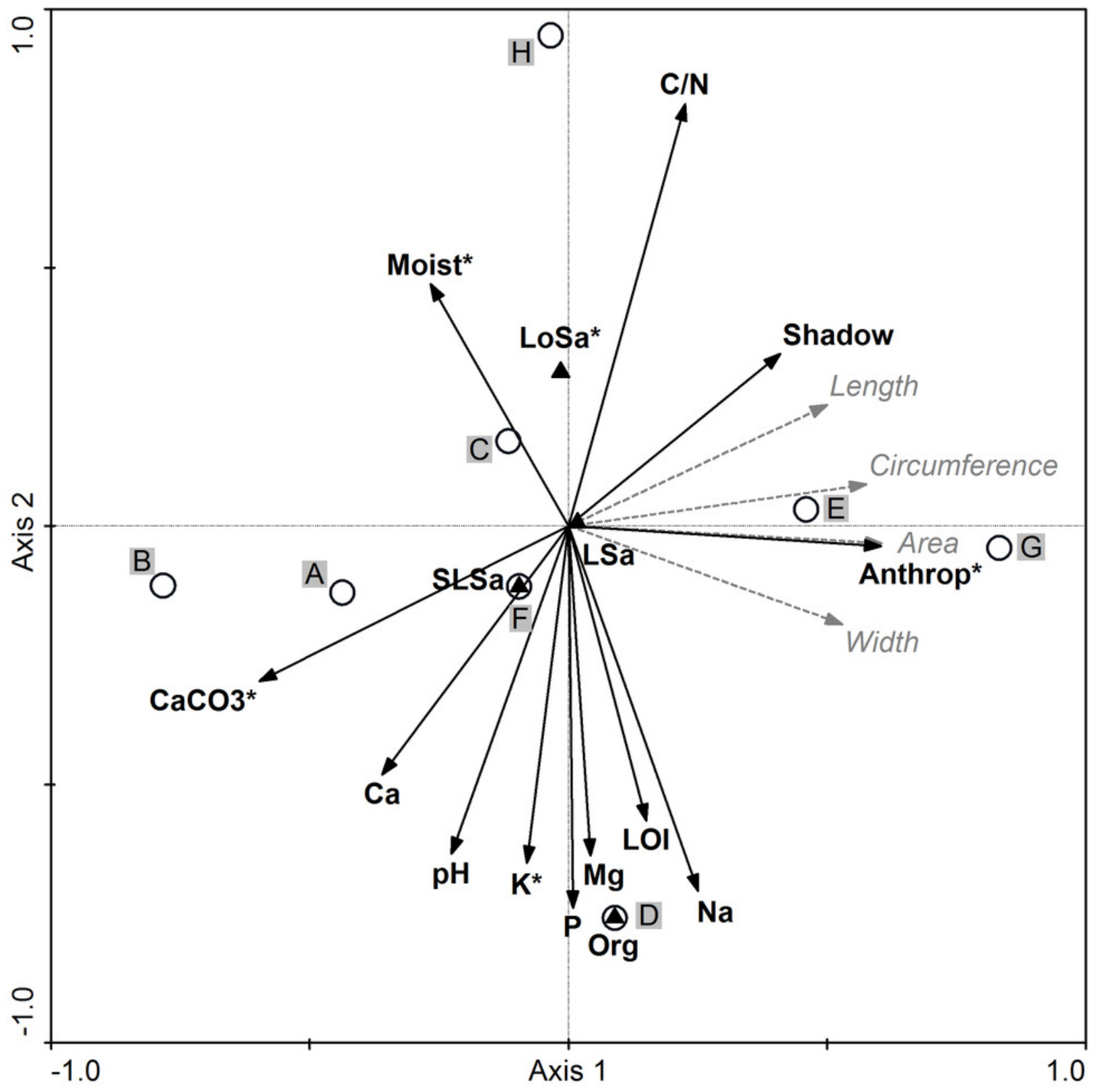




\section{Figure 5}

Comparison of seeds of Impatiens capensis Meerb.

(A-D) general view of seeds from (A) Czarnocin, (B) Police, (C) Lublin, (D) Podgrodzie; (E-F) seed sculpture; $(G)$ seed surface 3D ultrastructure between the ribs; $(\mathrm{H})$ rib; (I-L) cells near rib; (M) 3D ultrastructure of cells near rib. 

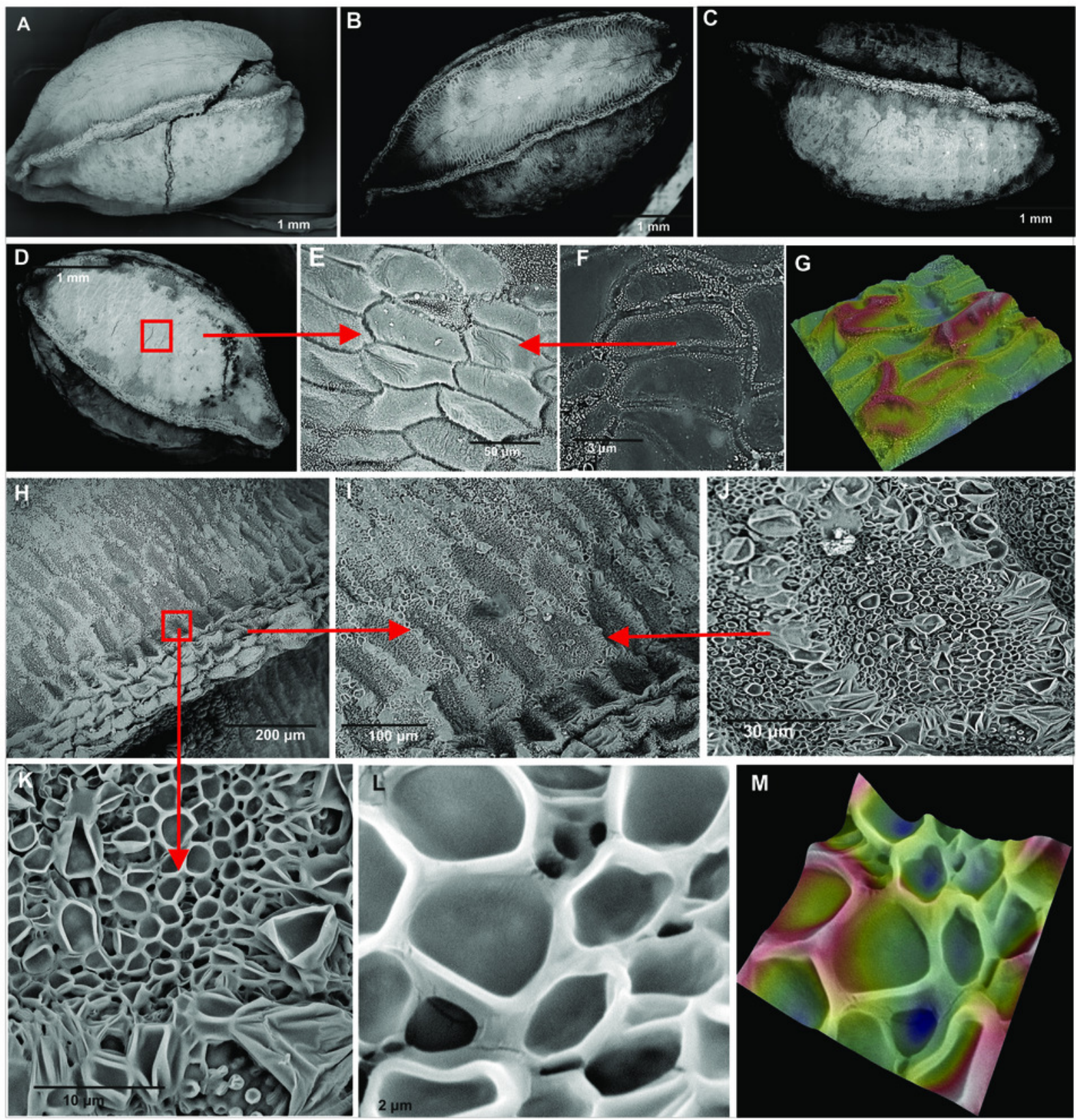


\section{Figure 6}

(A) Drawing of seed of Impatiens capensis (based on Bojňanský and Fargašová 2007), seed of Impatiens capensis under the light microscope; (B) general view; (C) rib.

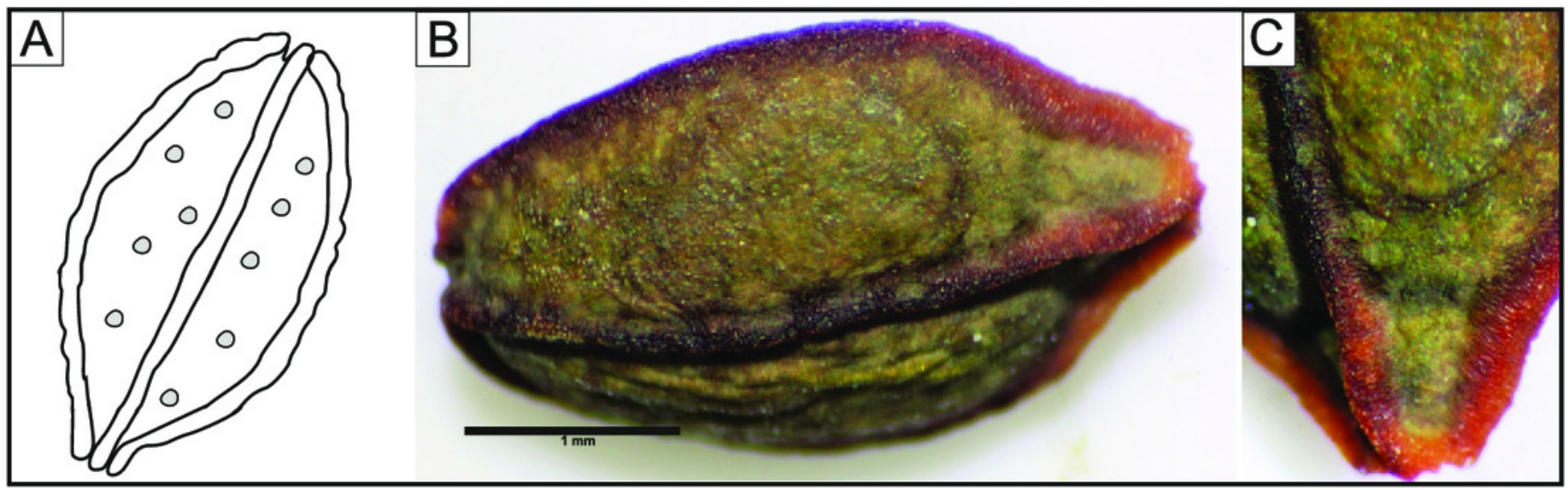

